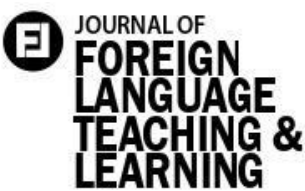

Volume 4, No. 2, 2019

Available online at: journal.umy.ac.id/index.php/FTL/issue/view/581

\begin{abstract}
Mariska Intan Sari
earned her bachelor's degree in

English Literature focusing on

English Linguistics from

Yogyakarta State University. She

then obtained her master's

degree in Applied Linguistics

from Ohio University. She has

taught at the English Language

Education Department of

Universitas Muhammadiyah

Yogyakarta since 2012. Her

research interests are reading,

writing, and CALL or the use of technology in language learning.
\end{abstract}

\section{The Use of Web 2.0 Tools for Learning in EFL \\ Context: Pre-service Teachers' Voice}

\author{
Mariska Intan Sari \\ Universitas Muhammadiyah Yogyakarta \\ mariska.intan@umy.ac.id
}

DOI: $18196 / \mathrm{ftl} .4243$

\begin{abstract}
Information and communication technology (ICT) has always been evolving, and its advancement has affected every aspect of human life, including education. As future teachers, pre-service teachers need to be aware of this development and have to be able to follow suit by learning how to utilize the technology for their teaching and learning processes. In English as a Foreign Language (EFL) context, Web 2.0 tools have been widely used since they provide opportunities for the users to have interaction and collaboration with other people from around the world, and, thus, open the opportunity to global learning. Therefore, this research aims to explore the Web 2.0 tools that have been employed by the pre-service teachers, and it also aims to examine the benefits they perceived in applying some of the Web 2.0 tools for their learning process in the EFL context. The results of the research show that there are five types of Web 2.0 tools that the pre-service teachers used, namely video sharing platforms, social networking tools, social photo tools, blogs, and game-based learning platforms. Concerning the benefits of using Web 2.0 tools in the learning process in the EFL context, the pre-service teachers stated that they could help them to find information more easily, allow them to collaborate with other people, enhance their language skills, and increase their motivation.
\end{abstract}

Keywords: pre-service teachers, Web 2.0 tools, EFL context 


\section{Introduction}

The advancement of information and communication technology (ICT) in this Industrial Revolution 4.0 Era has affected every aspect of people's life, including the education aspect. Both teachers and students are affected in some ways in that they might get the benefits as well as the challenges from the use of technology in the learning process, and this has become inevitable in this era. The teachers have to be well aware that their current students are digital natives who have been exposed to technology from a very young age. Whereas, the students, as the digital natives, must be ready to utilize technology if they do not want to be left behind. Based on the survey data from Asosiasi Penyelenggara Jasa Internet Indonesia or Indonesian Internet Service Providers Association (2018), in Indonesia alone, 143.26 million out of 262 million people used the internet in 2017. The data also show that $75.50 \%$ of school-age students between 13 to 18 used the internet for various purposes, but they mostly used chatting tools and social media.

The internet users in Indonesia has been increasing each year. Data from Hootsuite (in Riyanto, 2019) show that the internet users in Indonesia in 2018 had increased to 150 million from the total population of 268.2 million people, which was then $56 \%$ of the total population. The data also show that all of them are active social media users, and that 130 million of them are mobile social media users or people who actively access social media from mobile devices. It also highlighted that in 2018, the time Indonesian spent to access the internet was approximately eight hours and 36 minutes, in that three hours and twenty-six minutes were spent using social media via any device, two hours and fifty-two minutes were spent watching broadcast streaming and video on demand, and one hour and twenty-two minutes were spent listening to streaming music. Furthermore, it can be seen from the data that $79 \%$ of the Indonesian internet users access the internet every day. Hence, considering the condition, the teachers shall promote the best way to use ICT to create the best learning environment for the students to enhance their learning, whereas the students must also learn to get the best out of the ICT for their learning process since they have been exposed to ICT in their daily lives.

Nowadays, the use of ICT for learning is mostly related to Web 2.0 tools. It is because they provide opportunities for the users to not only browse and read the 
static content on the internet as in Web 1.0 technology, but also to write, post, and interact online on the world wide web (Balbay \& Erkan, 2018). Moreover, Aşıksoy (2018) claims that Web 2.0 technologies also allow students to control their learning instead of relying heavily on their teachers. Also, Web 2.0 tools might be used by a vast array of subjects or disciplines. Therefore, Web 2.0 tools have been increasingly used in the EFL context.

Many studies have been conducted regarding the utilization of Web 2.0 tools in English language teaching and learning. These studies have reported different findings. Some of them favor the implementation of Web 2.0 tools for English language learning. A positive attitude has been revealed among teachers who have utilized Web 2.0 technology in their teaching and learning process (Ajjan $\&$ Hartshorne, 2008; Balbay \& Erkan, 2018). Not only teachers, but students also have a positive attitude regarding the implementation of Web 2.0 tools in language learning, in that it can increase their motivation to learn, and thus enhancing their language skills (Aşıksoy, 2018; Eren, 2012). However, several studies reveal that even though students and teachers believed that the implementation of Web 2.0 positively affects language teaching and learning process, its application is still very limited in that they are unenthusiastic to incorporate it in the teaching and learning process (Faizi, 2018; Hartshorne \& Ajjan, 2009).

However, most of the studies concerning Web 2.0 tools were conducted to find the effect of the implementation of Web 2.0 tools on the students' vocabulary acquisition, motivation, attitudes, and awareness, and the effectiveness of the tools. Most of the studies having students as the subjects of the research were conducted to EFL students. Thus, this research aims to scrutinize the pre-service teachers' lived experiences in utilizing Web 2.0 tools for their teaching and learning process. Also, this research aims to find out the Web 2.0 tools used by the pre-service teachers in the EFL context. The research questions are formulated as follows:

1. What Web 2.0 tools have pre-service teachers used for learning in the EFL context?

2. What are the benefits of using Web 2.0 tools for learning in the EFL context perceived by pre-service teachers?

\section{Literature Review}

Definitions of Web 2.0 Tools

The term Web 2.0 was introduced by O'Reilly (2005) to refer to web-based 
technology, facilitating, promoting and sharing communication among users worldwide. Blogs, wikis, podcasts, RSS feeds, aggregators, social bookmarks, among others, are concepts ingrained in this new approach to global interaction that have been rapidly adopted by the e-learning community.

There are many kinds of Web 2.0 tools available on the world wide web. Aşıksoy (2018) had divided these tools into eight categories. They are blogs, social networking tools, podcasts, video sharing platforms, social photo tools, voice threads, and YouTube. There are some blogpublishing services available nowadays, such as Blogger, WordPress, Tumblr, Weebly, and LiveJournal. Also, there are some social networking tools available, among others are Facebook, WhatsApp, and Twitter. The podcast can be used in language learning to share audio to improve students' listening skills. Thus, both students and teachers have many choices in utilizing Web 2.0 tools for their teaching and learning processes, depending on their objectives.

\section{The Benefits of Using Web 2.0 Tools in}

\section{Language Learning}

Web 2.0 tools have provided learners with new opportunities to learn things outside the classroom through the internet (Ajjan \& Hartshorne, 2008; Aş1ksoy, 2018; Greenhow, Robelia \& Hughes, 2009). The teachers can share information through some online applications, whereas the students can access it through those online applications, as well as by other experts through some Web 2.0 tools on the internet. Several studies reveal that the Web 2.0 tools environment has enhanced the interaction between teachers and students and among students, leading to a better and richer language learning process (Aşıksoy, 2018).

Studies on the use of Web 2.0 tools in language learning have shown that they provide some benefits for the students. One of the commonly mentioned benefits is to find information (Aşıksoy, 2018; Rahimi, van der Berg, \& Veen, 2015). It is because students can access the information from many resources directly on the internet. There are many options that students can choose, such as reading blogs, reading from Wikipedia, reading from the language learning online application, and reading news. The second benefit that Web 2.0 tools have offered to students is that they help the students to become active internet users, meaning that they do not only become the consumers of the information given on the internet, but also the producers of the information by sharing the knowledge they 
learned through social media, blogs, or another Web 2.0 tools available in the world wide web (Huffman, 2017). Besides, students can acquire better the information they get through Web 2.0 tools since they carry out active learning through these tools, making it possible for them to retain the information in their brain (Cochrane, 2014).

The fourth benefit of using Web 2.0 tools in language learning is that they provide an environment allowing students to collaborate with their fellow students both in the same and different contexts (Barbara \& Linda, 2013). It means that the Web 2.0 tools enable students to interact and collaborate with their fellow students in their schools as well as with other students from other schools in their countries, or even from different countries all over the world. This way, the students' minds will also be broadened since they will get different perspectives from different people in different countries.

The fifth benefit that Web 2.0 tools offered to students is the dynamic and flexibility they possess (Aşıksoy, 2018; Cochrane, 2014; Rahimi, van der Berg, \& Veen, 2015). It means that by employing Web 2.0 tools in language learning, students can learn at their pace, anywhere and anytime they want. It may help students since they have different abilities in absorbing information and in understanding a particular concept. Some studies also reveal that the use of Web 2.0 tools in language learning has, in some ways, increased students' motivation because they offered different platforms that can avoid students from being bored to learn both inside and outside the classroom and because they might turn the students from passive to active learners (Aşıksoy, 2018; Huffman, 2017).

\section{Methodology}

This section elaborates on the research design. It also explains the research participants, the setting of the place, and the time the researcher conducted the research. The instruments of the study and the rigor are also described in this section.

Research design. A qualitative research design was applied in this research. Using a phenomenological approach, the researcher describes the lived experiences of the participants on a specific phenomenon to find similar traits among them (Creswell, 2007). In this research, the phenomenon under study was the utilization of Web 2.0 tools among pre-service teachers in the EFL context. Since the focus of this study is the description of participants' lived experience, instead of the interpretation of the 
researcher, the transcendental type of phenomenological study by Moustakas (in Creswell, 2007) was employed. Therefore, this study used constructivism as the worldview in that the study investigated the meaning of participants' experiences.

Participants. The research participants were five EFL pre-service teachers who were currently taking a bachelor's degree in English Education Department at a large private university in Yogyakarta (EED of PUY) when this study was conducted. There were three criteria used by the researcher in choosing the participants. That the participants were actively enrolled in courses at EED of PUY during the research is the first criterion. The second criterion is that the participants were at least in the second year of their study, meaning that they have taken the two technology-for-language-teaching-and-

learning-based courses, namely Computer Literacy Online and Innovative Technology. The participants need to have taken these courses to ensure that they have sufficient background knowledge about Web 2.0 tools. By joining these two courses, they learned how to use and apply some Web 2.0 tools for the teaching and learning process. The third criterion is that the participants had utilized some Web 2.0 tools in learning English. Thus, they have enough experience to share for this research. To find the participants, the researcher employed convenience sampling; the researcher chose the individuals nearest to her who can be contacted easily (Cohen, Manion \& Morrison, 2011). The five participants consist of two males (Michael and Andrew) and three females (Lucy, Jennifer, and Rose) EFL pre-service teachers at ELED of PUY from batch 2017. It means that they were interviewed in the second year of their study. They had taken and passed the two technology-for-language-teaching-andlearning-based courses. The names of the participants were changed into pseudonyms to maintain the confidentiality of the participants.

Data collection method. A semistructured interview was used to collect the data. Therefore, the researcher created a semi-structured interview guideline. The guideline covered the kinds of Web 2.0 tools used by pre-service teachers for their learning in the EFL context, and their experiences in utilizing the tools for learning, which also included the benefits they perceived and the challenges they faced. The interviews were conducted on the preservice teachers in a comfortable place agreed by the two parties. The interviews were voice-recorded to avoid the missing of the data, and the records were kept in a safe 
place to ensure the confidentiality of the participants. The researcher also did notetaking throughout the interview to help the researcher in making the follow-up questions whenever needed so that rich data on the participants' experience could be collected.

Reliability and validity. The reliability and validity of the findings and data interpretations were conducted through member checking. These were carried out by sending the interview transcripts along with the interpretations to be reviewed by the participants. The participants were allowed to check whether the transcript and researcher's interpretations are correct, correct mistakes if any, and add further information if necessary. Cohen et al. (2011) indicate that member checking is a respondent validation in that a researcher allows respondents to check whether the data and the interpretations are correct, correct errors, and add further information. The researcher then analyzed and elaborated on the findings after the participants approved the data.

\section{Findings}

With the advancement of technology in this industrial revolution 4.0 era, the implementation of Web 2.0 tools in the language classroom is inevitable since they might provide opportunities for a better environment to learn the language, especially in the EFL context. Thus, investigating the kinds of Web 2.0 tools used by pre-service teachers in learning the language in the EFL context, and also the benefits they perceived in utilizing them is crucial, in that it can provide insights on what is good about it.

\section{The Web 2.0 Tools Used By Pre-service} Teachers for Learning in EFL Context

When asked about what Web 2.0 tools are, pre-service teachers had given convincing answers, proving that they know about the tools. Then, it can be concluded that they were aware of the existence of these tools and that they could use them to support their language learning, in this case, English language learning. Andrew defined Web 2.0 tools as "the tools on the internet that we can use to obtain and share information." It shows that by using Web 2.0 tools technology, users are not only able to obtain information, but also to share information with others. Lucy also has the same understanding; she added that Web 2.0 tools are devices that "can promote collaborations among the users." It is in line with Jennifer, who stated that "Web 2.0 tools are the platform providing services by 
which the users can obtain and share information from one another." Thus, the notion of information sharing and collaborations of the Web 2.0 tools are wellunderstood by the five participants.

Regarding the Web 2.0 tools used by pre-service teachers in the EFL context to enhance their English language learning, they claimed that they had used various Web 2.0 tool platforms outside the classroom. They also claimed that each Web 2.0 tool has its benefits. Out of the seven categories given by Aşıksoy (2018), social networking tools, social photo tools, and video sharing platforms are the most widely used by preservice teachers. The followings are the Web 2.0 tools they utilized for their learning in the EFL context.

Video sharing platform. The most mentioned platform that the pre-service teachers used, which they perceived as helpful to enhance their English learning, is YouTube. Most of the participants of this research said that they frequently watched videos on YouTube. Michael stated, "I always search on YouTube whenever I need to know something; I always use YouTube as my reference." Some of them even watched YouTube every day. Jennifer mentioned, "I watch YouTube videos every day. I usually watch short movies, vlogs, and TEDTalks on YouTube." She further explained that watching videos on YouTube is not only beneficial for her language learning but also refreshing at the same time. She said, "I enjoy watching videos on YouTube rather than reading books." Rose also stated that she watched YouTube videos every day after school. She said, "I like watching videos on YouTube; I usually watch YouTube videos in my boarding house after coming back from campus; it is fun and entertaining." She mentioned that she had some favorites vloggers that she always watches on YouTube. The participants agreed that watching English videos on YouTube gave them more exposure to the English language, and they could indirectly learn English because most of the videos they watched were in English.

There is another video-based tool occasionally used by the participants, namely YouGlish. It is a part of YouTube services providing the users with the pronunciation of English words through clips from YouTube. Users can choose to listen to one of the accents, namely American English, British English, or Australian English, or all of them. Jennifer stated, "I like to check the pronunciation of new words in YouGlish since it provides many examples of how the words are pronounced." Andrew added, "What I like from YouGlish is that I can 
choose whether I want to listen to American, British, or Australian accent."

Social networking tools. Pre-service teachers also used social networking tools as one of the media to learn English. They used Facebook, Twitter, and WhatsApp to interact with others. By doing so, they claimed that they got benefits in terms of social interaction and communication skills such as information exchanges, cooperation, and turn-taking, including the language skills, which in this case is English as the target language. Michael mentioned that social media such as Facebook and Twitter could be a good place to practice his English even though not all his friends in the media speak the language. He further claimed that casual interaction on Facebook created a comfortable zone to express his feelings, ideas, and opinions. Lucy also shared the same opinion. She mentioned, "Facebook is one of the social media I often use. I sometimes wrote my status in English." She further explained that she found it beneficial for her learning since every time she wrote her status in English, she would make sure that she wrote it correctly before posting it.

Social photo tools. Another platform of Web 2.0 tools commonly used by pre-service teachers is the social photo tools. Included in this category is Instagram. Some of the pre-service teachers used
Instagram to share photos and their opinions along with the photo. They said that by doing these, they could share their opinions as well as ask others' opinions. Jennifer stated,

I usually use Instagram to share photos along with the caption, especially when I have an opinion about something; I will then use the 'ask a question' feature on Insta Story to ask for people's opinions regarding the topic I raise.

The interaction she got from giving and asking opinions from Instagram users provides exposure to English as the target language when they used it to communicate on Instagram. Jennifer further explained that before using the ask a question feature, she used to share photos with an opinion on her blog. However, she moved to Instagram because it was more user-friendly, and she could use her smartphone to do it. Rose also used Instagram to share photos; she also agreed that by using Instagram, she could indirectly practice her English by sharing her opinion through the caption, and by understanding the comments from her friends.

Blogs. Blogs have also been one of the platforms used by pre-service teachers to enhance their English learning. It turned out that some of them could enjoy the 
process of writing their posts on their blogs. Jennifer said that she learned how to write well in terms of content and the language because she realized that many people would be able to read her posts on the blog. Therefore, she had to be very careful in writing her posts on her blogs. She tried to minimalize the grammatical errors in her writing so that her readers could understand the content well.

Game-based learning platforms. Pre-service teachers also utilized some gamebased learning platforms such as Kahoot! and Quizlet. For some of them, the use of these game-based learning platforms could create fun learning. Through these platforms, learners could compete, and that was what made them fun. Andrew mentioned, "Kahoot! makes learning fun because of the competition among the learners and also the background music when playing the game." Michael also agreed that "Kahoot! is fun and motivating." Besides Kahoot! the participants also mentioned Quizlet as a game-based learning platform they used. Lucy stated that what made Quizlet fun was that many studies set available online. She added, "we can also create our own study sets based on our needs.”
The Benefits of Using Web 2.0 Tools in the EFL Context

When it comes to pre-service teachers' voices in using Web 2.0 tools in their teaching and learning process, all participants claimed that they like to use them because they could make learning English more fun and easier. Rose, one of the participants, stated, "By using the appropriate Web 2.0 tools, it is easier to learn the language. They can make learning language easier because we can learn it anywhere and anytime." Another participant, Michael, stated, “using Web 2.0 tools to learn language makes learning language more fun and easier." He added that Web 2.0 tools were beneficial in supporting English language learning, for example, learning vocabulary, grammar, and pronunciation. For example, he could easily check the pronunciation of certain words by opening YouGlish. All in all, all participants claimed that Web 2.0 tools were beneficial for them in learning English.

In terms of experience in using Web 2.0 tools for learning, the pre-service teachers mentioned that they got benefits from utilizing them. The benefits are as follows:

Finding information easily. The first benefit that pre-service teachers perceived in using Web 2.0 tools in learning 
language is able to find information easily. Michael mentioned, "I always check on YouTube or easily browse on Google to find information about anything, especially when I have an assignment." He added that finding information through the internet was faster than finding it manually by reading books or magazines. Jennifer also mentioned that it was easier to find information from YouTube or Google search. She said, "I can get information easily by searching on Google or YouTube to get videos, blog posts, or web content." Similar to Michael and Jennifer, Rose mentioned that she could find the information she needed for her learning or assignment on the internet using some Web 2.0 tools available online. This view is similar to Andrew's, who stated, "Web 2.0 tools facilitate us to obtain any knowledge and information we need anywhere and anytime; they make everything easier to access.”

Allowing collaboration with other users. Another benefit of using Web 2.0 tools is that students can collaborate with others, which can enhance their language learning. Web 2.0 tools such as Google Docs, Google Slides, Prezi, and Padlet allow their users to edit the same document online synchronously or asynchronously. The preservice teachers found this feature beneficial for them in that they could collaborate with their friends or group mates even though they could not find time to meet each other due to their different schedules. Andrew stated, "By using Web 2.0 tools, I can interact with my friends, and it is really helpful especially when I have an assignment.” Jennifer also stated,

When I have a group assignment from the lecturer and my friends and I cannot find the time to meet to discuss it, we can discuss it online, or we can even use for example google slides to create and edit our presentation together.

She found that using Web 2.0 tools could help her and her friends to work together to do the assignment even though they could not meet face-to-face. Rose also has a similar view that Web 2.0 tools allow the users to have a collaboration with other users.

Enhancing learners' language skills. The participants also said that using Web 2.0 tools could enhance their language skills, namely reading, writing, listening, speaking, and pronunciation skills. They could improve their skimming and scanning skills in reading and their reading comprehension performance by reading much information through websites and blogs on the world wide web, as stated by Jennifer and Lucy. Lucy mentioned, "I read a lot of things over 
the internet, and it helps me improve my scanning skills since I have to find the correct information; my understanding when reading English texts also becomes better." The Web 2.0 tools enhance the preservice teachers' pronunciation by listening through English videos available online on YouTube, or also by searching and watching video clips on YouGlish. There are some sites dedicated to English teaching and learning like BBC website so that the preservice teachers can learn a lot from them.

\section{Increasing learners' motivation.}

Motivation is essential in language learning. Having high motivation can be beneficial for students to achieve better results in their studies. Another benefit of utilizing Web 2.0 tools is that learning can be fun so that it can increase students' motivation to learn. Michael stated,

It was fun to use Web 2.0 tools. For example, when the teacher used Kahoot! in the class, I felt motivated to learn because it was fun to compete with my friends. Also, the background music was fun to listen too; it enlivened the atmosphere.

Jennifer added, "it feels good when we need information and can find it easily on the web. I feel more motivated to learn more and more." She further explained that the ease in finding information on YouTube and websites made her feel motivated to learn. Thus, Web 2.0 tools can motivate students to learn.

\section{Discussion}

The findings indicate that pre-service teachers are aware of the availability of Web 2.0 tools for their English learning and that these tools can enhance their language learning. It is in line with a study conducted by Aşıssoy (2018), reporting that most of the students who were the participants of the study were aware of the availability of the Web 2.0 tools and that these tools were believed to be able to enhance their English language learning. Therefore, these preservice teachers also utilized some of the Web 2.0 tools available online for their English learning.

The Web 2.0 tools that they employed both in and out of the classroom context are video sharing platforms, social networking tools, social photo tools, blogs, and game-based learning platforms. Video sharing platforms and social networking tools are among the tools that most of the pre-service teachers used. These findings are similar to previous studies of Aşıksoy (2018) and Kizil (2017), revealing that videosharing, especially YouTube and social media tools, are among the most used Web 2.0 tools among ELT students. They further 
explained that the reason why most students used YouTube was that it provided them with a large number of videos that they could choose based on their interest.

The second most used Web 2.0 tools among the pre-service teachers are social media, which are also similar to the findings of a previous study conducted by Aşıksoy (2018). It is because today's students are familiar with social media. They are exposed to social media every day, and these media provide opportunities for them to interact directly with people from all around the world, especially to the native speakers of English. As stated by Aşıksoy (2018) that the use of social media enables the students to learn language through social interaction.

The Web 2.0 tools used by preservice teachers were mostly chosen because they were easy to use, fun, and could be beneficial for them. The benefits of utilizing the tools are helping them finding information more easily, allowing collaborations with other people, enhancing their language skills, and increasing their motivation. The finding which states that Web 2.0 tools are enhancing pre-service teachers' language skills is in line with what Keleş (2013) has underlined that Web 2.0 tools have positive effects on the English learning skills for ELT students, and these students believed that. Similarly, Aşıksoy
(2018) highlights that Web 2.0 tools help students in learning English and motivate them to be autonomous learners who can regulate their learning. It is related to the first finding of this research, namely finding information easily so that they can be autonomous learners in finding the information they need anytime and anywhere they are. The finding of a study carried out by Aşıksoy (2018) shows that the use of Web 2.0 tools can enhance students' pronunciation, which is similar to the finding of this research. It can also be traced back to the kinds of Web 2.0 tools they used. Since most of them liked to use Youtube and YouGlish, it is normal for them to think that their pronunciation skill has increased since they were provided with pronunciation examples from the videos or clips.

\section{Conclusion and Suggestion}

It is expected that the findings of this research can contribute to the literature concerning the use of Web 2.0 tools for language learning in the EFL context. It can be concluded from the findings of the research that pre-service teachers were aware of the existence of the Web 2.0 tools available for them. This research found that there are five types of Web 2.0 tools they frequently used. The tools are video sharing platforms, social networking tools, social 
photo tools, blogs, and game-based learning platforms.

Besides knowing and using some of the Web 2.0 tools, they were aware that these tools could be beneficial in learning English. The benefits perceived by these preservice teachers are helping them to find information more easily, allowing collaborations with other people, enhancing their language skills, and increasing their motivation.

Furthermore, it can be concluded from the five participants of this research that the use of the Web 2.0 tool can make English learning easier and fun. Therefore, teachers must be aware of these conditions so that they can utilize more Web 2.0 tools in their classrooms to provide more exposure for these pre-service teachers so that they can maximize the use of these tools for their learning and their teaching later on after finishing their study.

\section{References}

Ajjan, H., \& Hartshorne, R. (2008). Investigating faculty decisions to adopt Web 2.0 technologies: Theory and empirical tests. The internet and higher education, 11(2), 71-80.

Asosiasi Penyelenggara Jasa Internet Indonesia (Indonesian Internet Service Providers Association). (2018). [Infographic from survey results]. Penetrasi $\mathcal{E}$ Perilaku Pengguna Internet Indonesia Survey 2017.
Retrieved from https://apjii.or.id/survei2017

Aşıksoy, G. (2018). ELT students' attitudes and awareness towards the use of WEB 2.0 technologies for language learning. Journal of Language and Linguistic Studies, 14(2), 240-251.

Balbay, S., \& Erkan, G. (2018). Perceptions of Instructors on Using Web 2.0 Tools in Academic English Courses. International Journal of Curriculum and Instruction, 10(2), 45-60.

Barbara N., \& Linda B., (2013). Changing academic teaching with Web 2.0 technologies. Innovations in Education and Teaching International, 51(3), 315-325. doi: 10.1080/14703297.2013.796727

Cohen, L., Manion, L., \& Morrison, K. (2011). Research methods in education $\left(7^{\text {th }}\right.$ ed). Abingdon, Oxon: Routledge.

Creswell, J.W. (2007). Qualitative inquiry and research design: Choosing among five approaches $\left(2^{\text {nd }} \mathrm{ed}\right)$. Thousand Oaks, CA: Sage Publications, Inc.

Cochrane, T. D. (2014). Critical success factors for transforming pedagogy with mobile Web 2.0. British Journal of Educational Technology, 45(1), 65-8.

Eren, Ö. (2012). Students' attitudes towards using social networking in foreign language classes: A Facebook example. International Journal of Business and Social Science, 3(20), 288. 294.

Faizi, R. (2018). Teachers' perceptions towards using Web 2.0 in language learning and teaching. Education and Information Technologies, 23(3), 1219. 1230.

Greenhow, C., Robelia, B., \& Hughes, J. E. (2009). Learning, teaching, and scholarship in a digital age: Web 2.0 and classroom research: What path 
should we take now? Educational researcher, 38(4), 246-259.

Hartshorne, R., \& Ajjan, H. (2009). Examining student decisions to adopt Web 2.0 technologies: theory and empirical tests. Journal of computing in higher education, 21(3), 183-198.

Huffman, K. (2017). Web 2.0: Beyond the concept practical ways to implement RSS, podcasts, and Wikis. Education Libraries, 29(1), 12-19.

Keleş, U. (2013). The perceptions of ELT students about the use of Web 2.0 tools, particularly wikis, in their future language classrooms (Doctoral dissertation). Retrieved from Bilkent University.

Kızıl, A. Ş. (2017). Exploring EFL learners' use of Web 2.0 tools: Preliminary findings. Pamukkale University Journal of Social Sciences Institute, 27, 28-40.

O'Reilly, T. (2005). What Is Web 2.0: Design Patterns and Business Models for the Next Generation of Software. Communications $\mathcal{E}$ Strategies, 65(1), 17 37.

Rahimi, E., van den Berg, J., \& Veen, W. (2015). Facilitating student-driven constructing of learning environments using Web 2.0 personal learning environments. Computers $\mathcal{E}$ Education, 81, 235-246.

Riyanto, A. (2019). [Infographic from survey results]. Hootsuite (We are Social): Indonesian Digital Report 2019. Retrieved from https://andi.link/hootsuite-we-aresocial-indonesian-digital-report-2019/ 